\title{
全身性疾患と関連する耳鼻咽喉科疾患 一ステロイド、免疫抑制剂の使い方一
}

\author{
順天堂越谷大学医学部附属 順天堂越谷病院内科学（リウマチ・膠原病） \\ 小林茂人 \\ I はじめに
}

耳鼻咽喉科領域でのステロイドや免疫抑制剤の使用に関して, 薬剤の基本的事項と ANCA 関連中耳炎または多発血 管炎性肉芽腫症（Granulomatosis with polyangiitis：GPA, Wegener's granulomatosis）に関連したステロイドや免疫抑 制剤などの使用法・注意点を記載する.

\section{1. ステロイド}

\section{II 基本的な薬剤の説明 1}

副腎皮質ステロイドは，さまざまなストレスから身を守り，生体の恒常性を保つ作用がある．合成されるステロイド は糖質コルチコイドなどから成る。ステロイドは細胞質内受容体に結合し，DNAに作用して，抗炎症作用，免疫抑制 作用を発揮する。ステロイドの用量は, 概して, 疾患の活動期の入院治療ではプレドニゾロン (PSL) 換算で 30 ～80mg/ 日である．また，ステロイドパルス療法がある，外来治療では $30 \mathrm{mg} /$ 日以下からはじめ，維持量（5mg/日程度）また はステロイド off とする. ステロイドの減量は時間をかけて少量ずつ行う.

ステロイドの副作用は, 糖尿病, 高血圧, 高脂血症, 感染症, 骨粗鬆症など知られている. 閉経後の女性や高齢者は, 脊椎の圧迫骨折が頻発し，長期臥床による廃用性萎縮などが問題になるため，ビスフォスフォネート製剤（処方例： ボノテオ $50 \mathrm{mg} 1 \mathrm{x}$ 起床時, 月に 1 回）による予防が重要である.

ステロイドの使用量を減らす目的のため (steroid sparing effect), 免疫抑制剂を併用することが勧められる.

2. 免疫抑制剂

1） アザチオプリン $(\mathrm{AZA}) \quad\left(\right.$ イララン ${ }^{\circledR}$, アザニン $\left.{ }^{\circledR}\right)$

6ーメルカプトプリン (6-MP) のプロドラッグで, 生体内で 6-MP に変換され，核酸合成を阻害して，細胞障害性 を示す，プリン拮抗薬である．1 日量は $1 \sim 2 \mathrm{mg} / \mathrm{kg}$ で，成人では 50〜 $100 \mathrm{mg} /$ 日，経口投与する．主な副作用は，内 服後の胃痛・不快感がある。また， $1 \sim 2$ 週間での血球減少，肝障害である。このため，投与後， 1 〜 週間後には血 算と肝機能は必ず調べる。それ以降の副作用の頻度は減少する。 ANCA 関連血管炎では維持療法の際に使用される.

2) ミゾルビン（ブレディニン ${ }^{\circledR}$ )

関節リウマチや全身性エリテマトーデスによるネフローゼ症候群に適用が認められている，プリン拮抗薬である。成 人で 100〜 150mg/日経口投与する. 海外で使用されているミコフェニレートモフェチィル（MMF：セルセプト初）と 同じ酵素を阻害し，リンパ球の核酸合成を選択的に抑制する。血中濃度を上げる目的のため，1日 1 回投与や間欠高用 量投与も行われている.

3）サイクロフォスファミド（CY）（エンドキサン ${ }^{\circledR}$ )

アルキル化剤で投与後に肝ミクロソーム p-450にて代謝され, 活性体となり, DNA 複製阻害し, 抗腫瘍作用を示す. 低用量によってとりわけBリンパ球に作用して免疫抑制作用を示す。経口では成人 1 日量で 50 〜 $100 \mathrm{mg} /$ 日を投与す る．副作用は骨髄抑制，出血性膀胱炎（代謝産物が膀胱を刺激して起こる），食欲不振がある，長期的には，生殖腺へ の影響（総投与量 $10 \mathrm{~g}$ )，発癌性がある．尿検査，血算，肝機能は毎回調べる，出血性膀胱炎の予防には，水分を摂取 と頻回の排尿を促す．出血性膀胱炎の際には，メスナ（ウロミテキサン ${ }^{\circledR}$ ) を点滴静中する.

4）メトトレキサート（MTX）（リウマトレックス ${ }^{\circledR}$, メトレート ${ }^{\circledR}$ )

葉酸拮抗剤で免疫抑制，抗炎症，抗リウマチ作用を示す。関節リウマチの基本薬である. 1 週間単位の間欠投与が原 則（12時間間隔で 3 回投与し，残り 5 日間は休薬）であるので注意する。毎日投与・処方しないこと.日本では関節り 


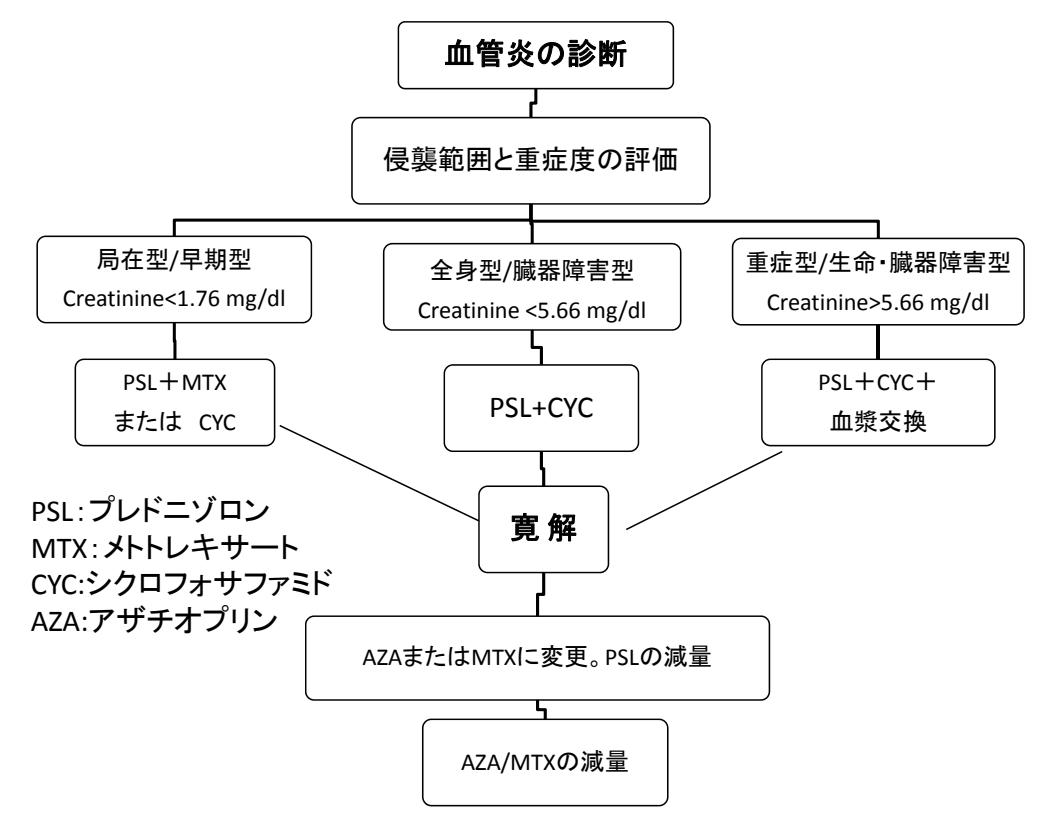

図 ANCA 関連血管炎の治療アルゴリズム（Rheumatol 2007：46：1615-16）

ウマチに対する治療として, 週 $16 \mathrm{mg}$ までの投与が認められている. 海外の血管炎に対する治療は最大 $20 \sim 25 \mathrm{mg} /$ 週 である. 腎排泄性のため, 高齢者では腎機能低下があり, 脱水の際に血中濃度が増加し, 汎血球減少を来し易いので 注意する。間質性肺炎には注意する。 口内炎, 肝障害に対しては, 最終投与後 1 日あけて葉酸（フォリアミン®） $5 \mathrm{mg}$ を処方する. MTXによる副作用発症時, MTX 投与 3 時間に, ロイコボリンき $15 \mathrm{mg}$ を 3 時間毎に 9 回静注し, 以後 6 時間每に 8 回筋注または静注する（MTX・ロイコボリン救援療法）。わが国では MTX は血管炎治療に対して保険適 応は承認されていない.

3. その他の薬剂

1） ST 合剂 (バクタ $\left.{ }^{\circledR}\right)$

Pneumocystis jitroveci（旧 carinii）感染は, 急減に起こり, 緊急入院などが必要になる. 通常の外来検査で, $\beta-D-$

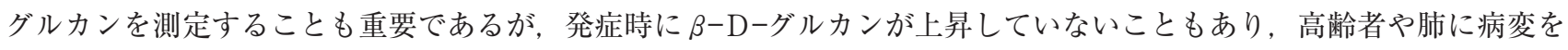
認める症例には，バクタ®の予防投与が勧められる。 1 日 2 錠, 朝夕の 2 回投与で十分である. 副作用は多くないが, 血算, 肝機能は投与後には検查する必要がある. ST 合剤は寛解後の GPA に対して寛解維持率がプラセボ群に比べ有意 に良好だったことから，GPAの症例に対しては積極的に投与すべき薬剤と考えられる.

\section{ANCA 関連血管炎に対する治療 ${ }^{2}$}

ANCA 関連血管炎は難治性・希少疾患である.すなわち，1）致死的（life-threatening）な疾患であり, 生命の維持 が保たれたとしても，2）全身の重要臟器の非可逆的な障害が起こる，また，3）治療経過中に致死的事象が起こるこ ともあり，また，治療薬剤（ステロイドやサイクロフォスファミド）によって重篤な副作用を引き起こすことがある。 ステロイド治療を行わないと 5 年生存率は $10 \%$ で, ステロイド治療によって 5 年生存率が $50 \%$ になり, ステロイドとサ イクロフォスファミドの併用療法によって 5 年生存率がはじめて $80 \%$ に達した。 このため, 現在は副作用や合併症の予 防・減少に関する改善策が考案されている.

1）寬解導入療法

PSL $(1 \mathrm{mg} / \mathrm{kg} /$ 日) に加え, 経口 CY ( $2 \mathrm{mg} / \mathrm{kg} /$ 日, 最高 $200 \mathrm{mg} /$ 日) または点滴静中 CY (IVCY) $15 \mathrm{mg} / \mathrm{kg}$ （最高 1 回 投与量 $1,500 \mathrm{mg})$ を 2 週間ごとの併用が推奨されている. 経口 CY $(2 \mathrm{mg} / \mathrm{kg})$ は 3 カ月投与する. 寛解に達すれ ば, $1.5 \mathrm{mg} / \mathrm{kg}$ に減量する. CY の投与期間は 6 カ月を超えないようにする. 感染症のリスク低下のため, 白血球数 $4,000 / \mu \mathrm{L}$ 以上，好中球 $2,000 / \mu \mathrm{L}$ 以上に保つように投与量を調整する，IVCYは十分な補液をし，十分な飲水を指示す 
る.はじめの 3 回は 2 週間おきに行い, その後, 3 週おきに行う. $3 \sim 6$ カ月で維持療法に移行することを目標とする. 高齢者, 腎機能障害, 白血球減少が危険因子のため注意する。

2) 寛解維持療法

CYによる出血性膀腅炎や膀腅癌などの悪性腫瘍発症が高いため，CY をメトトレキサート（MTX）またはアザチオ プリン（AZA）に変更し，低用量の PSL の併用療法を行う，寛解が12カ月継続すれば，慎重に減量してもよいが，寛 解維持療法は18～24カ月は継続する．再発を考慮して 5 年間は慎重に観察するか，もしくは治療を継続する.

$$
\mathrm{N} \text { ま め }
$$

治療薬剂に精通して，寛解の導入・維持を目指すことが重要である.

\section{参考文献}

1）竹内 勤：リウマチ性疾患に使用される薬剤，治療法。リウマチ病学テキスト。治療と診断社，2011：p 468-495.

2）尾崎承一, 渥美卓也，天野宏一，他：ANCA 関連血管炎の診療ガイドライン 厚労省難治性疾患克服事業報告書 2011. (http ://minds4.jcqhc.or.jp/minds/ANCA/anca.pdf より入手可能) 